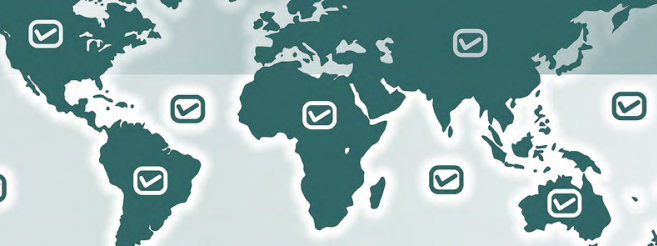

NOTES ON GEOGRAPHIC DISTRIBUTION
Check List 11(4): 1692, 13 July 2015 doi: http://dx.doi.org/10.15560/11.4.1692 ISSN 1809-127X @ 2015 Check List and Authors

\title{
New distribution records and notes on the habitat of Magneuptychia flavofascia Zacca \& Siewert, 2014 (Lepidoptera:
Nymphalidae)
}

\author{
Lucas A. Kaminski ${ }^{1,2 *}$, Rafael Dell'Erba ${ }^{3}$, Eduardo P. Barbosa ${ }^{2}$ and André V. L. Freitas ${ }^{2}$ \\ 1 Institut de Biologia Evolutiva (CSIC-UPF), Passeig Marítim de la Barceloneta, 37, 08003 Barcelona, Spain \\ 2 Departamento de Biologia Animal and Museu de Zoologia, Instituto de Biologia, Universidade Estadual de Campinas, CP 6109, 13083- \\ 970, Campinas, SP, Brazil \\ 3 Museu de Zoologia da Universidade de São Paulo, Avenida Nazaré 481, Ipiranga, 04263-000, São Paulo, SP, Brazil \\ * Corresponding author. E-mail: lucaskaminski@yahoo.com.br
}

\begin{abstract}
The recently described butterfly Magneuptychia flavofascia was formerly known from only two localities in the Brazilian Cerrado savanna. Here, we report new distribution records, DNA barcode sequences, and information on the habitat, adult behavior and systematic position of this species.
\end{abstract}

Key words: Chapada dos Guimarães, DNA barcoding, grassland butterflies, Paryphthimoides, Satyrinae

The Brazilian savanna vegetation named Cerrado originally covered an area of over two million square kilometers in Central Brazil (Oliveira and Marquis 2002). It is the most extensive savanna in South America, presenting high species richness and endemism (including butterflies; see Brown and Gifford 2002) and is considered a global hotspot of biodiversity (Mittermeier et al. 2005). The vegetation consists of savannic tree-shrub formations in the well-drained interfluves with gallery forests along the watercourses (Figure 1). Different vegetation types are included under Cerrado sensu lato, whose physiognomies vary from pure grassland, through savanna with different woody biomass, to mesophytic forests in richer soils (Oliveira-Filho and Ratter 2002).

Recently, Zacca et al. (2014) described Magneuptychia flavofascia Zacca \& Siewert, 2014, a species of Satyrinae from the Brazilian Cerrado. This species was described based on museum specimens collected in the 1960s and 1970s. In addition to being recorded from only two localities, there is a lack of information about its habitat preference and behavior. Here, we report recent new distribution data and DNA barcode sequences, and we discuss information about habitat, adult behavior and systematic position.
The species was studied in the field at Parque Nacional da Chapada dos Guimarães (PNCG), Chapada dos Guimarães municipality, Mato Grosso state, Brazil. The park contains almost all Cerrado physiognomies, with altitudes ranging from 200 to $900 \mathrm{~m}$ (for details see Pinto and Oliveira-Filho 1999). The study was carried out along two different trails, $5 \mathrm{~km}$ long, each containing three sampling units, $2 \mathrm{~km}$ apart. Each sampling unit consisted of five portable bait traps (see Uehara-Prado et al. 2007). The traps were spaced linearly along trails in the Cerrado sensu stricto of PNCG, suspended $0.8-1.5 \mathrm{~m}$ above the ground, with a distance of at least $20 \mathrm{~m}$ between adjacent traps. A standard mixture of mashed banana and sugar cane juice, fermented for at least $48 \mathrm{~h}$, was used as the attractant. The bait was placed inside the traps in plastic pots with a perforated cover. The traps were checked and the baits replaced every $24 \mathrm{hr}$ over four days. Sampling was done in December 2012 and March, May and June 2013. Additionally, sampling with entomological nets was also done in different vegetation types in PNCG, including gallery forests, mesophytic forests, and open Cerrado areas, totaling a sampling effort of $\sim 100$ nethours. Adults were collected with entomological nets and legs were removed from each individual and kept for DNA barcoding analysis. The mitochondrial gene Cytochrome C Oxidase I (CoxI, ca. 658 bp) was amplified by using the following primer combination: $\mathrm{LCO}+\mathrm{HCO}$ (Folmer et al. 1994). Reactions were done in a $25 \mu \mathrm{L}$ final volume using $2 \mu \mathrm{L}$ of total DNA, $2.0 \mathrm{mM}$ of $\mathrm{MgCl}_{2}$, $40 \mu \mathrm{M}$ of dNTPs, $0.5 \mu \mathrm{M}$ of each primer, $1 \mathrm{U}$ of GoTaq DNA Polymerase (Promega, Madison, Wisconsin, USA), and $10 \%$ of $1 \mathrm{X}$ Taq buffer. The amplification program included an initial denaturation step at $95^{\circ} \mathrm{C}$ for $5 \mathrm{~min}$, followed by 35 cycles of denaturation at $94^{\circ} \mathrm{C}$ for $30 \mathrm{~s}$, annealing at $42^{\circ} \mathrm{C}$ for $30 \mathrm{~s}$, and polymerization at $72^{\circ} \mathrm{C}$ 


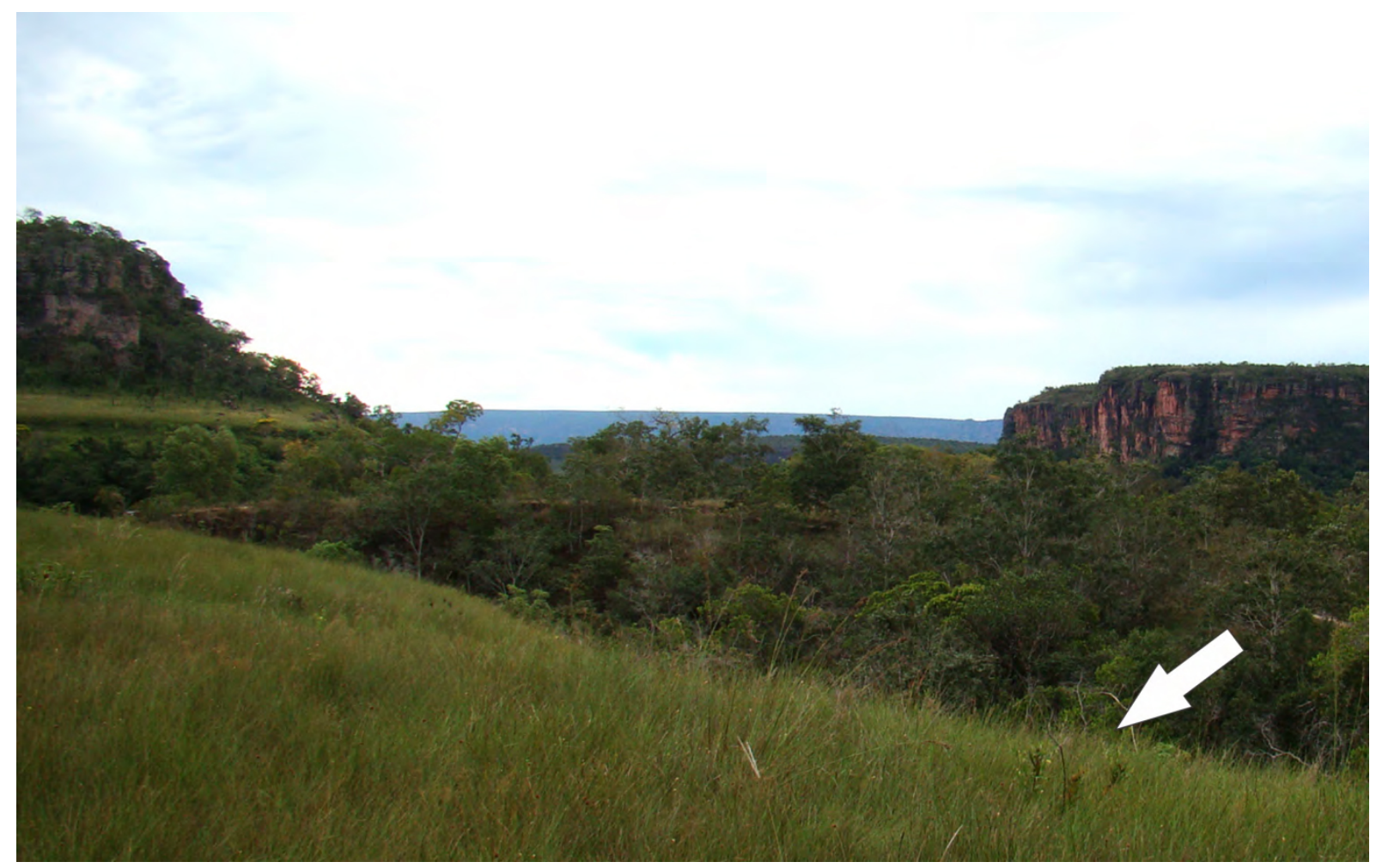

Figure 1. General view of the Magneuptychia flavofascia habitat in Chapada dos Guimarães, state of Mato Grosso, Brazil; specimens were observed in areas of contact between gallery forests and the Cerrado savanna (arrow).

for $1 \mathrm{~min}$, followed by an extension step at $72^{\circ} \mathrm{C}$ for 10 min (Silva-Brandão et al. 2005). PCR products were purified of primers and deoxynucleotides with ExoSAPIT (GE Healthcare, Buckinghamshire England), and then sequenced by ABI Prism BigDye Kit protocol in a 3500xL Genetic Analyser (Applied Biosystems - Hitachi), with primers used for amplification.

\section{Additional distribution data for Magneuptychia flavofascia}

BRAZIL: Distrito Federal: Brasília: Parque do Gama, 2 females, 23-26.ii.1968; 3 males and 2 females, 14-17.v.1969; 2 males and 3 females, 07.ii.1970; Brown Jr. leg. Mato Grosso: Chapada dos Guimarães - Parque Nacional da Chapada dos Guimarães $\left(15^{\circ} 40^{\prime} \mathrm{S}\right.$, $055^{\circ} 83^{\prime}$ $\mathrm{W}, 590-600 \mathrm{~m}$ above sea level), 3 males and 1 female, 01.VI.2013; 1 male, 25.XI.2013; Kaminski and Dell'Erba leg. Material deposited in the Museu de Zoologia da Universidade Estadual de Campinas (ZUEC), Unicamp, Campinas, São Paulo, Brazil.

\section{Molecular data}

DNA sequences of CoxI from four individuals were obtained (DNA vouchers YPH-0485, YPH-0488, YPH-0489 andYPH-049o); GenBankaccession numbersare KP994892, KP994893, KP994894 and KP994895 respectively.

\section{Habitat and behavior of Magneuptychia flavofascia}

Adults of M. flavofascia were only observed in areas of contact between gallery forests and the Cerrado savanna (Figure 1). Extensive censuses inside the gallery forests, mesophytic forests, and cerrado areas (both with entomological nets and bait traps) in the Chapada dos Guimarães showed that $M$. flavofascia was absent in these habitats, being observed exclusively in the interface between open vegetation and forest. This habit preference reported for $M$. flavofascia is distinct to that observed for several other species of Magneuptychia, which are associated with forest habitats (e.g., DeVries 1987; Kaminski and Freitas 2008). For example, the three widespread species Magneuptychia libye (Linnaeus, 1767), Magneuptychia pallema (Schaus, 1902), and Magneuptychia ocypete (Fabricius, 1776), were only observed inside the gallery forests and the mesophytic forests in the same region (R. Dell'Erba, pers. obs.), never syntopic with $M$. flavofascia. This same pattern was observed in Diamantino (MT), where M. flavofascia is found only in rocky Cerrado sites near gallery forests (E. Furtado, pers. comm.). The habitat requirements that might explain its localized distribution are unknown and need to be investigated in detail.

The reported habitat preference of $M$. flavofascia is potentially important information for understanding not only its ecology and natural history, but also its systematic position. The genus Magneuptychia is clearly polyphyletic (Peña et al. 2010), and preliminary phylogenetic analysis (unpublished results), comparing the barcode sequences of $M$. flavofascia with available sequences of other species of Euptychiina, recovered the species close to Paryphthimoides poltys (Prittwitz, 
1865), a species of open habitats, and not to the forest species of Magneuptychia. It is also interesting that the old specimens here reported (from the former collection of Keith S. Brown Jr., and now part of ZUEC), were identified by Dr. Keith Brown as an "undescribed species of Erichthodes Forster, 1964", and not as a species of Magneuptychia. These results suggests that all morphological similarities of $M$. flavofascia with other Magneuptychia are either convergences or plesiomorphies of the "Splendeuptychia clade" (sensu Peña et al. 2010).

In summary, the purpose of this report is to provide biological information for this recently described species, and we hope that the information may be useful and encourage further studies of this butterfly endemic to the Brazilian Cerrado.

\section{ACKNOWLEDGEMENTS}

We thank SISBIOTA/ComCerrado for the logistic support. We also thank PNCG staff, specially Carolina Potter, Cintia Brazão and Eduardo Barcellos, who facilitated the work in the Park, and to ICMBio for the research permits (SISBIO $n^{\circ} 36917-3$ and 10802-5). Keith Willmott read the last version of the manuscript, making valuable contributions. Eurides Furtado shared unpublished habitat occurrence data. LAK was supported by $\mathrm{CNPq}$ (163119/2013-9) and CAPES (3200-14-0), and RDE acknowledges CNPq (563134/2010-0). EPB acknowledges FAPESP (2012/03750-8) for a graduate fellowship. AVLF was supported by CNPq (fellowship 302585/2011-7), and the National Science Foundation (DEB-1256742). This publication is part of the RedeLep "Rede Nacional de Pesquisa e Conservação de Lepidópteros" SISBIOTA-Brasil/CNPq (563332/2010-7), of the project "Identificação Molecular de Biodiversidade de Invertebrados Terrestres" (Grant 564954/20101) included in the "Rede Nacional de Identificação Molecular da Biodiversidade-BR-BoL" (MCT/CNPq/ FNDCT 50/2010), and of the BIOTA-FAPESP Program (2011/50225-3).

\section{LITERATURE CITED}

Brown Jr., K. S. and D. R. Gifford. 2002. Lepidoptera in the Cerrado landscape and the conservation of vegetation, soil, and topographical mosaics; pp. 201-222, in: P.S. Oliveira and R.J. Marquis. (Eds.). The Cerrados of Brazil: ecology and natural history of a Neotropical savanna. New York: Columbia University Press.
DeVries, P.J. 1987. The butterflies of Costa Rica and their natural history: Papilionidae, Pieridae, Nymphalidae. New Jersey: Princeton University Press. xxii +328 pp.

Folmer, O., M. Black, W. Hoeh, R. Lutz and R. Vrijenhoek. 1994. DNA primers for amplification of mitochondrial cytochrome $c$ oxidase subunit I from diverse metazoan invertebrates. Molecular Marine Biology and Biotechnology 3: 294-299.

Kaminski, L.A. and A.V.L. Freitas. 2008. Immature stages of the butterfly Magneuptychia libye (Linnaeus) (Lepidoptera: Nymphalidae: Satyrinae). Neotropical Entomology 37: 169-172.

Mittermeier, R.A., P.R. Gil, M. Hoffman, J. Pilgrim, T. Brooks, C.G. Mittermeier, J. Lamoreux, G.A.B. Fonseca, P.A. Seligmann and H. Ford. 2005. Hotspots revisited: earth's biologically richest and most endangered terrestrial ecoregions. Mexico: CEMEX. 390 pp.

Oliveira, P.S. and R.J. Marquis. 2002. The Cerrados of Brazil: ecology and natural history of a Neotropical savanna. New York: Columbia University Press. 424 pp.

Oliveira-Filho, A.T. and J.A. Ratter. 2002. Vegetation physiognomies and wood flora of the Cerrado biome; pp. 91-120, in: P.S. Oliveira and R.J. Marquis. (eds.). The Cerrados of Brazil: ecology and natural history of a Neotropical savanna. New York: Columbia University Press.

Peña, C., S. Nylin, A. V. L. Freitas and N. Wahlberg. 2010. Biogeographic history of the butterfly subtribe Euptychiina (Lepidoptera, Nymphalidae, Satyrinae). Zoologica Scripta 39: 243-258. doi: 10.1111/j.1463-6409.2010.00421.x

Pinto, J.R.R. and A.T. Oliveira-Filho. 1999. Perfil florístico e estrutura da comunidade arbóreo-arbustiva de uma floresta de vale no Parque Nacional da Chapada dos Guimarães. Revista Brasileira de Botânica 22: 53-67.

Silva-Brandão, K. L., A.V.L. Freitas, A.V.Z. Brower and V.N. Solferini 2005. Phylogenetic relationships of the New World Troidini swallowtails (Lepidoptera: Papilionidae) based on COI, COII, and EF-1 alpha genes. Molecular Phylogenetics and Evolution 36: 468-483. doi: 10.1016/j.ympev.2005.04.007

Uehara-Prado, M., K. S. Brown Jr. and A.V.L. Freitas. 2007. Species richness, composition and abundance of fruit-feeding butterflies in the Brazilian Atlantic Forest: comparison between a fragmented and a continuous landscape. Global Ecology and Biogeography 16: 43-54. doi: 10.1111/j.1466-8238.2006.00267.x

Zacca, T., R.R. Siewert, O.H.H. Mielke and M.M. Casagrande. 2014. A new species of Magneuptychia Forster, 1964 (Lepidoptera: Nymphalidae: Satyrinae) from Brazilian Savanna. Zootaxa 3795: 71-78. doi: 10.11646/zootaxa.3795.1.7

Authors' contribution statement: LAK and AVLF conceived the study, LAK led the writing, LAK and RD collected the data, EPB performed the molecular analysis, all authors contributed in the form of discussions and suggestions, and approved the final manuscript.
Received: 9 August 2014
Accepted: 9 June 2015
Academic editor: Cristiano A. Iserhard 